dos siê
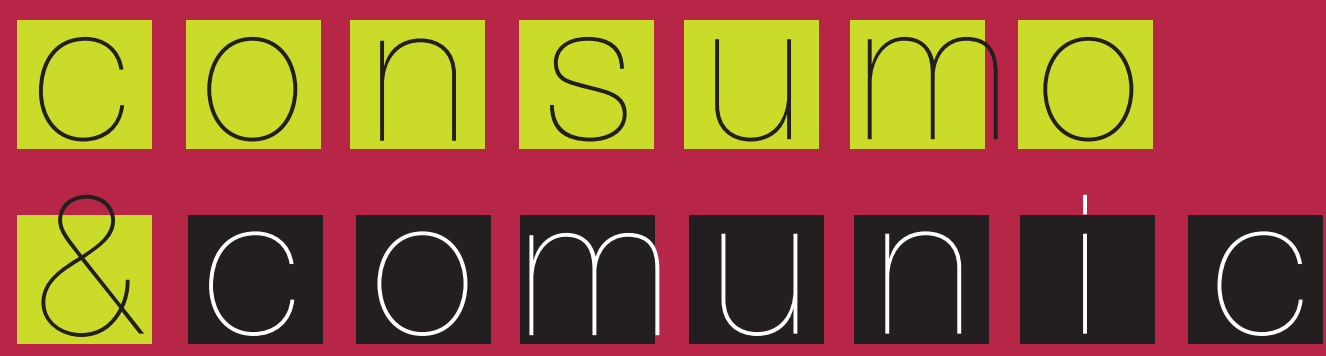

a ç ã o 
Dossiê Consumo e Comunicação.

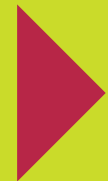




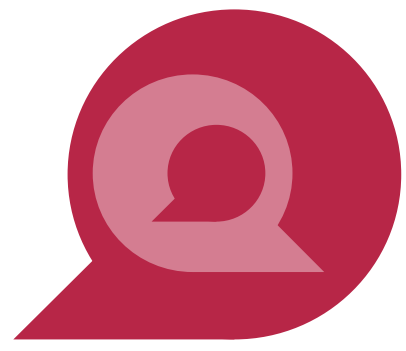

\section{Mídia, Consumo e Sociedade}

LILIAN MUNEIRO *

ARYOVALDO DE CASTRO AZEVEDO JUNIOR **

Consumo é inerente aos seres vivos. Consomem ar e alimentos para moverem as máquinas orgânicas e assim, manterem-se ativos em busca de mais ar e alimentos num ciclo incessante, rompido somente pelo homo sapiens que não mais queria se limitar a sobreviver.

Dominaram o fogo, desenvolveram a linguagem, criaram histórias, inventaram ferramentas, cultivaram novas formas de produzir em escala, o que possibilitou sua expansão pelo mundo, construindo cidades, estabelecendo novas relações sociais e se tornando a espécie dominante do planeta.

Tudo derivado do consumo, da busca irrefreável por energia, transmutada em conforto, bem estar e felicida-

\footnotetext{
* Doutora em Comunicação e Semiótica (2010) pela Pontifícia Universidade Católica de São Paulo. Professora Adjunta do Departamento de Comunicação da Universidade Federal do Rio Grande do Norte (UFRN).

** Pós-Doutor em Ciências da Comunicação pela Universidade de São Paulo (2017), Doutor em Multimeios pelo Instituto de Artes da Universidade Estadual de Campinas (2005). Professor Associado do Departamento de Comunicação e do Programa de Pós-Graduação em Comunicação da UFPR.
} 
de. Com o desenvolvimento de sociedades mais complexas, tornou-se necessário estabelecer comunicações mais efetivas que a oral ou pictórica. Houve o desenvolvimento de outras linguagens e o ser humano ampliou a capacidade de comunicar (e progredir).

Ao utilizar-se de plataformas variadas na ânsia de comunicar, criou aquilo que hoje chamamos de mídias. Estas foram desenvolvidas e tornadas ubíquas a ponto de se integrarem ao ser humano em si, numa fusão tecnológica que se plasma ao organismo vivo e gera configurações mutantes que podem levar a humanidade a um novo estágio de desenvolvimento, pós-humano. Apocalíptico? Redentor?

Impossível saber o futuro, exceto que a integração entre consumo e mídia é onipresente na vida contemporânea e terá forte influência em sua construção. E, este dossiê busca iluminar um pouco deste ecossistema orgânico-digital que caracteriza a sociedade em que vivemos e na qual o consumo tem papel central.

O conjunto de artigos, vindos de diferentes regiões geográficas, variadas matrizes culturais e diversas instituições de ensino superior, como Universidade Federal do Paraná (PR), Universidade do Vale do Rio dos Sinos (RS), Universidade Estadual de Londrina (PR), Faculdade Cásper Líbero (SP), Universidade Federal do Rio Grande do Norte (RN), Universidade Regional de 
Blumenau (SC), Universidade Federal da Bahia (BA), Universidade Tuiuti (PR), Centro Universitário Internacional (PR), Universidade Feevale (RS), Universidade Positivo (PR), Universidade de São Paulo (SP), Universidad Nacional de Jujuy (Arg) e Universidad de Guadalajara (Mex), apresenta um panorama sobre o consumo e busca compreender suas diferentes relações, sejam econômicas, políticas, biológicas, midiáticas, sociais, psicológicas, tecnológicas, emocionais etc.

$\mathrm{O}$ dossiê inicia com o artigo A criação de circuitos de consumo nas cidades a partir da ressignificação dos territórios urbanos, onde Sérgio Trein pontua sobre como novos processos de midiatização podem promover a ressignificação de espaços da urbe. Em Consumo, publicidade e crises ambientais, Eduardo Nogueira e Sonia Mansano evidenciam a necessidade de uma análise crítica sobre a efetividade das práticas ambientais na contemporaneidade. No texto de Luis Pérez-Amezcua, "Postmodern or postmortem?": El mito del canibal en el cine del siglo XXI, o autor reflete sobre o consumo enquanto metáfora da solidão e da falta de comunicação.

Na sequência, Fábio Caim versa sobre a questão de gênero e as características da masculinidade hegemônica na linguagem publicitária com Consumo e Gênero: revisitando as singularidades masculinas nas comunicações publicitárias. Em De papel y tinta: estudio del libro desde 
el consumo cultural, Vanina Canavire reflete sobre o livro enquanto produto industrial e objeto cultural, e aponta a valorização de sua dimensão simbólica pelos leitores/ consumidores destes produtos culturais. Retomando a questão do gênero na publicidade, Patrícia Nunes e Josimey Costa retratam a objetificação da representação feminina na mídia comercial em Representações da Mulher na Publicidade em Natal-RN: entre Corpos Estéticos e Padrões Hegemônicos da Subalternidade na Cena Pública.

Em $O$ discurso publicitário da felicidade: conexões com o consumo e o desenvolvimento, Clóvis Reis, Cynthia Quadros e Yanet Barrios abordam a relação entre a busca da felicidade pelo estímulo ao consumo e o funcionamento da máquina (economia) capitalista. O imbricamento entre mídia e religião é exposto na relação de consumo de telenovelas pelo público evangélico no texto $O$ consumo da telenovela pelos pentecostais: entre tensões e negociações de Rita Matos, Catiane Souza, Priscila Chéquer e Caio Nascimento. No artigo Envelhecimento Intolerável: Consumo Midiático e o Imaginário do Corpo, Denise Stacheski expõe a exaltação midiática de valores simbólicos associados à juventude, em detrimento do processo natural de envelhecimento.

Hertz Camargo, Marina Sabbi, Clovis T. Filho e Marcia Boroski abordam o tema da segmentação de conteúdo e a interação nas mídias sociais com Tipos de 
Conteúdo e Engajamento: um estudo sobre o consumo de fanpages de casas noturnas LGBT. A dinâmica da mutação do papel da mulher na comunicação promocional em A (Des)Construção do Papel da Mulher Em Campanhas Publicitárias de Cerveja: Análise da Campanha Reposter da Skol é abordada por Cristiano Pinheiro, Débora Wissmann e Camila Ferrareli. No artigo O consumo de yoga a partir de experiências etnográficas, Filipe Bordinhão e Anna Penteado refletem sobre consumo ritualístico e a mediação social relacionados a este transcendente produto cultural.

Em O Consumo de Causas Sociais na Era da Midiatização Digital, Valéria Brandini analisa a relação entre consumidores, marcas, comunicação digital e a aderência a causas sociais como estratégia de branding. E, para encerrar o dossiê, escolhemos o ensaio "Bem-vindo à próxima fase": a cultura do choque e o fim do tédio, em que Rodolfo Londero nos leva a refletir sobre como tendemos a (re)agir numa sociedade caracterizada pela hiperinformação.

Esperamos que o conjunto de reflexões apresentadas neste dossiê ajude a desbravar as relações entre consumo, mídia e sociedade. Boa leitura!

Lilian Muneiro \& Aryovaldo Azevedo Jr. Organizadores 
Consumption and Communication Dossier.

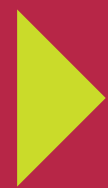




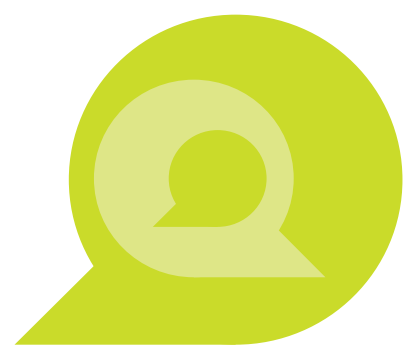

\section{Media, Consumption and Society}

LILIAN MUNEIRO *

ARYOVALDO DE CASTRO AZEVEDO JUNIOR **

Consumption is inherent in living things. They consume air and food to move organic machines and thus keep themselves active seeking more air and food in an endless cycle, only broken by homo sapiens, who no longer wanted to simply survive.

He mastered fire, developed language, created stories, invented tools, cultivated new ways of producing in larger scale, which enabled him to spread around the world, build cities, establish new social relations and become the dominant species on the planet.

All these things were derived from consumption, from the unrestrained search for energy transmuted into comfort, well-being and happiness. As a result of the development of more complex societies, it became neces-

\footnotetext{
* PhD on Communication and Semiotics (2010) at Pontifícia Universidade Católica de São Paulo. Adjunct Professor in the Communication Department at Federal University of Rio Grande do Norte (UFRN).

** Post-Doctor on Communication Sciences at São Paulo University (2017), PhD on Multimedia at State University of Campinas (2005). Associate Professor in the Communication Department and Postgraduate Program in Communication at the Federal University of Paraná.
} 
sary to establish more effective forms of communication than oral or pictorial ones. There has been the development of other languages and the human beings widened their ability to communicate (and to make progress).

By using a variety of platforms in the eager to communicate, they created what is now known as media. They have been developed and made ubiquitous up to a point of being integrated with the human beings themselves, in a technological fusion which takes shape in the living organism and creates mutant configurations that can lead humanity to a new, post-human stage of development. Apocalyptic? Redeemer?

It is impossible to predict the future, but for the fact that the integration between consumption and media is omnipresent in contemporary life and will heavily influence its construction. This dossier aims to put light on this organic-digital ecosystem that characterise the society in which we live and in which consumption plays a central role.

The set of articles come from different geographic regions, varied cultural matrices and several undergraduate and graduate institutions, as the Universidade Federal do Paraná (PR), the Universidade do Vale do Rio dos Sinos (RS), the Universidade Estadual de Londrina (PR), the Faculdade Cásper Líbero (SP), the Universidade Federal do Rio Grande do Norte (RN), the Universidade 
Regional de Blumenau (SC), the Universidade Federal da Bahia (BA), the Universidade Tuiuti (PR), the Centro Universitário Internacional (PR), the Universidade Feevale (RS), Universidade Positivo (PR), the Universidade de São Paulo (SP), the Universidad Nacional de Jujuy (Arg) and the Universidad de Guadalajara (Mex). The dossier presents an overview of consumption and aims to provide a better understanding of its different relations, whether economic, political, biological, media, social, psychological, technological, emotional, etc.

The dossier begins with the article The creation of circuits of consumption in cities through the resignification of urban territories, in which Sérgio Trein studies how the new process of mediatisation can promote the re-signification of spaces of the city. In Consumption, Advertising and Environmental Crises: a critical analysis from a case study, Eduardo Nogueira and Sonia Mansano highlight the need for critical analysis of environmental practices' effectiveness in contemporary times. In Luis Pérez-Amezcua's text "Postmodern or postmortem?": The myth of the cannibal in the xxist century cinema, the author reflects on consumption as a metaphor for loneliness and lack of communication.

Following, Fábio Caim deals with the question of gender and characteristics of the hegemonic masculinity in advertising language in Consumption and Gender: 
revisiting male singularities in advertising. In Of paper and ink: study of the book from the cultural consumption, Vanina Canavire reflects on books as an industrial product and cultural objects pointing to the appreciation of its symbolic dimension by readers/consumers of cultural products. Taking up gender issues in advertising, Patrícia Nunes and Josimey Costa portray the objectification of the representation of women in Representations of Women in Advertisement in Natal-RN: among Aesthetic Bodies and Hegemonic Patterns of Subalternity in the Public Scene.

In The advertising discourse of happiness: connections with consumption and development, Clóvis Reis, Cynthia Quadros and Yanet Barrios discuss the relations between the pursuit of happiness by stimulating consumption and the functioning of the capitalist machine (economy). The interweaving of media and religion is presented in the consumption relation of soap operas by the evangelical public in the text The Consumption of Soap Opera by Pentecostal Religious: Between Tensions And Negotiations, written by Rita Matos, Catiane Souza, Priscila Chéquer and Caio Nascimento. In the article Intolerable Aging: Media Consumption and the Imaginary of the Body, Denise Stacheski exposes the mediatic exaltation of symbolic values which are associated with youth rather than the natural process of ageing.

Hertz Camargo, Marina Sabbi, Clovis T. Filho and 
Marcia Boroski discuss content segmentation and the interaction in social media in the article Types of Content and Engagement: a study on the consumption of LGBT nightclubs fan pages. The dynamics of the changing role of women in promotional communication in The (Des) Construction of the Role of Women in Beer Advertising Campaigns: Skol's Reposter Campaign Analysis is discussed by Cristiano Pinheiro, Débora Wissmann and Camila Ferrareli. In the article The consumption of yoga from ethnographic experiences, Filipe Bordinhão and Anna Penteado reflect on ritual consumption and social mediation related to this transcendent cultural product.

In The Consumption of Social Causes in the Age of Digital Mediatization, Valéria Brandini analyses the relations among consumers, brands, digital communication and the adherence to social causes as branding strategy. Finally, the last text chosen is the essay "Welcome to the next level": the culture of shock and the end of boredom, in which Rodolfo Londero makes us ponder over how we tend to (re)act in a society characterised by the hyperinformation.

We hope that the set of reflections presented in this dossier may help you to explore the relations among consumption, media and society.

We wish you a good reading!

Lilian Muneiro \& Aryovaldo Azevedo Jr. organizers 